\title{
A new genus and species of golden coral (Anthozoa, Octocorallia, Chrysogorgiidae) from the Northwest Atlantic
}

\author{
Stephen D. Cairns', RalfT. S. Cordeiro² \\ I Department of Invertebrate Zoology, National Museum of Natural History, Smithsonian Institution, PO Box \\ 37012, MRC 163, Washington, DC 20013-7012, USA 2 Programa de Pós-Graduação em Biologia Animal, \\ Universidade Federal de Pernambuco, Av. Prof. Moraes Rego, 1235, Cidade Universitária, Recife, PE, CEP: \\ 50670-901, Brazil
}

Corresponding author: Stephen D. Cairns (cairnss@si.edu)

Academic editor: B.W. Hoeksema | Received 9 February 2017 | Accepted 2 April 2017 | Published 12 April 2017

http://zoobank.org/A3F5117B-BEAF-4F6C-B6E9-0C45EAC261A9

Citation: Cairns SD, Cordeiro RTS (2017) A new genus and species of golden coral (Anthozoa, Octocorallia, Chrysogorgiidae) from the Northwest Atlantic. ZooKeys 668: 1-10. https://doi.org/10.3897/zookeys.668.12203

\begin{abstract}
A new genus and species of unbranched golden coral, Flagelligorgia gracilis, is described based on several specimens collected off the southeastern coast of the United States. The genus is provisionally included in the family Chrysogorgiidae, pending molecular confirmation. Flagelligorgia morphologically resembles other unbranched chrysogorgiids, such as Distichogorgia, Chalcogorgia, Helicogorgia and Radicipes, to which it is compared. The type species is illustrated and its distribution mapped.
\end{abstract}

\section{Keywords}

Flagelligorgia gracilis, unbranched octocoral, biserial polyp arrangement, Radicipes, southeastern USA

\section{Introduction}

Chrysogorgiids form a polyphyletic family of octocorals (Pante et al. 2012), which is distributed in all oceans throughout the world (Watling et al. 2011). Most of its genera are in need of revision, some of which require reallocation into new families (Pante et al. 2012). In the course of doing a revision of the genus Radicipes Stearns, 
1883 (see Cordeiro et al. in press), an unusual species was encountered that was similar to species in that genus that were already known, but was consistently different from them in several characters. Although no recently collected specimens were available for molecular analysis, sufficient alcohol-preserved specimens were present at the NMNH to describe the new species and the new genus in which it is placed.

\section{Material and methods}

All specimens are preserved in ethanol (70\%) and deposited at the National Museum of Natural History. Reference material of all species of Radicipes was also examined (Cordeiro et al. in press). The terminology used in the description follows that of Bayer et al. (1983). Preparation of polyps for SEM to reveal sclerites includes short digestion (four seconds) of superficial coenenchyme, rinsing several times in distilled water, and drying at room temperature.

Abbreviations used in the text include: Alb - USFWS Albatross, L:W - length to width ratio of a sclerite, MCC - Monophyletic Chrysogorgiidae Clade sensu Pante et al. (2012), NMNH - National Museum of Natural History, Smithsonian Institution, USNM - United States National Museum (now known as the NMNH, but acronym still used for catalog numbers).

\section{Taxonomy}

Subclass Octocorallia Haeckel, 1866

Order Alcyonacea Lamouroux, 1812

Suborder Calcaxonia Grasshoff, 1999

\section{Family Chrysogorgiidae Verrill, 1883}

Chrysogorgidae Verrill 1883: 21.

Chrysogorgiidae: Versluys 1902: 2-4; Bayer 1956: F216; Bayer and Muzik 1976: 6769 (key to genera); Bayer 1979: 876-878 (key to genera); Cairns 2001: 748-754 (synonymy); Pante and France 2010: 600 (key to genera); Watling et al. 2011: 68-74 (distribution maps of all genera); Pante et al. 2012: 1-12 (phylogenetic and bathymetric analyses).

Type genus. Chrysogorgia Duchassaing \& Michelotti, 1864.

Diagnosis (after Cairns (2001) and Pante et al. (2012)). Calcaxonians having an unjointed, solid (non-spicular), concentrically layered scleroproteinous axis. The axial layers are usually smooth (not undulated) and thus not longitudinally grooved externally; the axis usually displays metallic or iridescent reflections. The colony may be branched or unbranched (flagelliform), arising from a root-like or discoidal, strongly 
calcified holdfast. Polyps are contractile but not retractile, arranged in rows (uniserial, biserial or multiserial), but never in whorls. Sclerites predominantly flat, smooth scales, in some species warty rods and spindles.

Remarks. Fourteen genera have been assigned to the Chrysogorgiidae, but based on sequencing of three genes, Pante et al. (2012) have suggested that only six of these genera belong to Chrysogorgiidae sensu stricto, which they call the Monophyletic Chrysogorgiidae Clade, or MCC. They imply that the other genera may belong to as many as three other, as yet undescribed, families. The six genera of the MCC are keyed by Pante and France (2010) and their worldwide distributions plotted by Watling et al. (2011). They are further discussed by Pante et al. (2012) in the context of a phylogenetic analysis. Flagelligorgia is morphologically most similar to Radicipes, which is part of the MCC, but lacking material suitable for molecular analysis, the placement of Flagelligorgia in that family can only be a suggestion at this time. In fact, we did attempt to sequence four genes (COI, mtMutS, $28 S$ and $18 S)$ from specimens collected in 1964 with no results.

Distribution. Worldwide, 31-4492 m depths (Pante and Watling 2011: 6).

\section{Flagelligorgia gen. $\mathbf{n}$.}

http://zoobank.org/0C142EEB-5AD6-4EE5-A654-F0C5DD669E79

Type species. Flagelligorgia gracilis, here designated. Gender: feminine.

Diagnosis. Colonies unbranched (flagelliform), loosely coiled, attached by a holdfast; axis composed of undulating concentric layers (Figs 1C-E, 2D). Polyps arranged biserially. Body wall and coenenchymal scales elongate, smooth scales. Polyps lack an operculum.

Remarks. Until 1956 (Bayer 1956) the Chrysogorgiidae had been divided into three subfamilies, one being the Lepidogorgiinae Versluys, 1902, consisting of genera with an unbranched colony and lacking polyp opercula. However, the subfamily classification has been ignored for decades and is not supported by molecular evidence. Nonetheless, it is incumbent to compare Flagelligorgia to the four other unbranched chrysogorgiid genera. Helicogorgia Bayer, 1981, known only from the east coast of Africa at 66-775 $\mathrm{m}$ depth range, is unbranched but has its polyps arranged in a multiserial fashion on one side of the stem, a naked track displayed on the opposite side. Furthermore, its body wall scales are irregular plates and its coenenchymal scales are spindles. For all of these reasons Helicogorgia is easily distinguished from Flagelligorgia. Based on sequencing of three genes, Pante et al. (2012) indicate that Helicogorgia might constitute a family on its own, as sister to the Chrysogorgiidae. Helicogorgia was revised by Williams (1992), recognizing four species in the African coast.

Chalcogorgia Bayer, 1949, known only from its type locality off northwestern Cuba at $708 \mathrm{~m}$ depth, is also unbranched and has biserially arranged polyps, like Flagelligorgia, but differs in having eight triangular opercular scales on each polyp, and body wall scales shaped as irregularly shaped platelets. According to Pante et al. (2012: 
8), based on "very limited data," Chalcogorgia was suggested to ally with Helicogorgia, and thus also outside of the MCC.

Distichogorgia Bayer, 1979, known only from the Blake Plateau off Florida at 814 $\mathrm{m}$ depth, is unbranched and has biserially arranged polyps, but differs in having unique body wall scales consisting of two fans of longitudinally arranged, blade-like scales, one on each side of the polyp, interspersed with tiny pointed sclerites, similar to its coenenchymals. Pante et al. (2012) did not report sequencing data for this genus, but based on its biserially polyps, they suggested an affinity with Helicogorgia and Chalcogorgia in a family separate from the Chrysogorgiidae.

Perhaps most similar to Flagelligorgia is the genus Radicipes Stearns, 1883, consisting of 9-10 species (see Cordeiro et al., in press), which occurs worldwide at depths of 241-3580 m. Radicipes is unbranched but differs from Flagelligorgia in having uniserially arranged polyps, and a body wall and coenenchymal sclerites that are rod-shaped to compressed rod-shaped. Furthermore, chrysogorgiids (MCC), including Radicipes, are characterized by having an axis formed by non-undulated (smooth) concentric layers (Bayer 1956), which is not the case for Flagelligorgia. Based on molecular evidence Pante et al. (2012) placed Radicipes firmly in the Chrysogorgiidae clade (MCC), as the sister genus to Chrysogorgia. Lacking molecular evidence for Flagelligorgia (all specimens are quite old), it is not possible at this time to determine if it is allied with Radicipes in the Chrysogorgiidae (based on similarity of body wall sclerites) or the other cluster of genera including Helicogorgia, Chalcogorgia and Distichogorgia (based on polyp arrangement), which may constitute an as yet undescribed family.

Distribution. Off Southeastern United States from North Carolina to Florida, 196-567 m depths.

Etymology. The name is a combination of flagellum (Latin for small whip) and gorgia (a common octocoral suffix and once the name of the order Gorgonacea, the name derived from the mythical female monster, the Gorgon), in reference to the flagelliform nature of the colony.

\section{Flagelligorgia gracilis sp. $\mathbf{n}$.}

http://zoobank.org/579269D2-B012-4C73-A854-E743F7154252

Figs $1-4$

Material examined (Types). Holotype: Alb-2666, 1 specimen now in two pieces, USNM 49503. Paratypes: Alb-2601, 34³9'15"N, 33³0'10"W, 196 m, 1 colony, USNM 16607, 18 October 1885; Alb-2602, 343'ㅇ' $30^{\prime \prime N}, 75^{\circ} 33^{\prime} 30^{\circ} \mathrm{W}, 227$ m, 1 colony, USNM 16821, 18 October 1885; Alb-2666, 3047'30"N, 7949'W, 494 m, 33 colonies, SEM stubs 2364-2367, USNM 14458, 5 May 1886; Alb-2667, 30 $53^{\circ} \mathrm{N}$, 79²' $30^{\circ}$ "W, 499 m, 40 colonies, USNM 14457, 5 May 1886; Gerda-179, 2741'N, $79^{\circ} 11^{\prime} \mathrm{W}, 549-567 \mathrm{~m}, 9$ colonies, USNM 57315, 1 July 1963; Megalopa, $11.2 \mathrm{~km}$ SSE of Carysfort Reef, Florida Keys, 205 m, 9 July 1950, 1 colony, USNM 51956, 9 July 


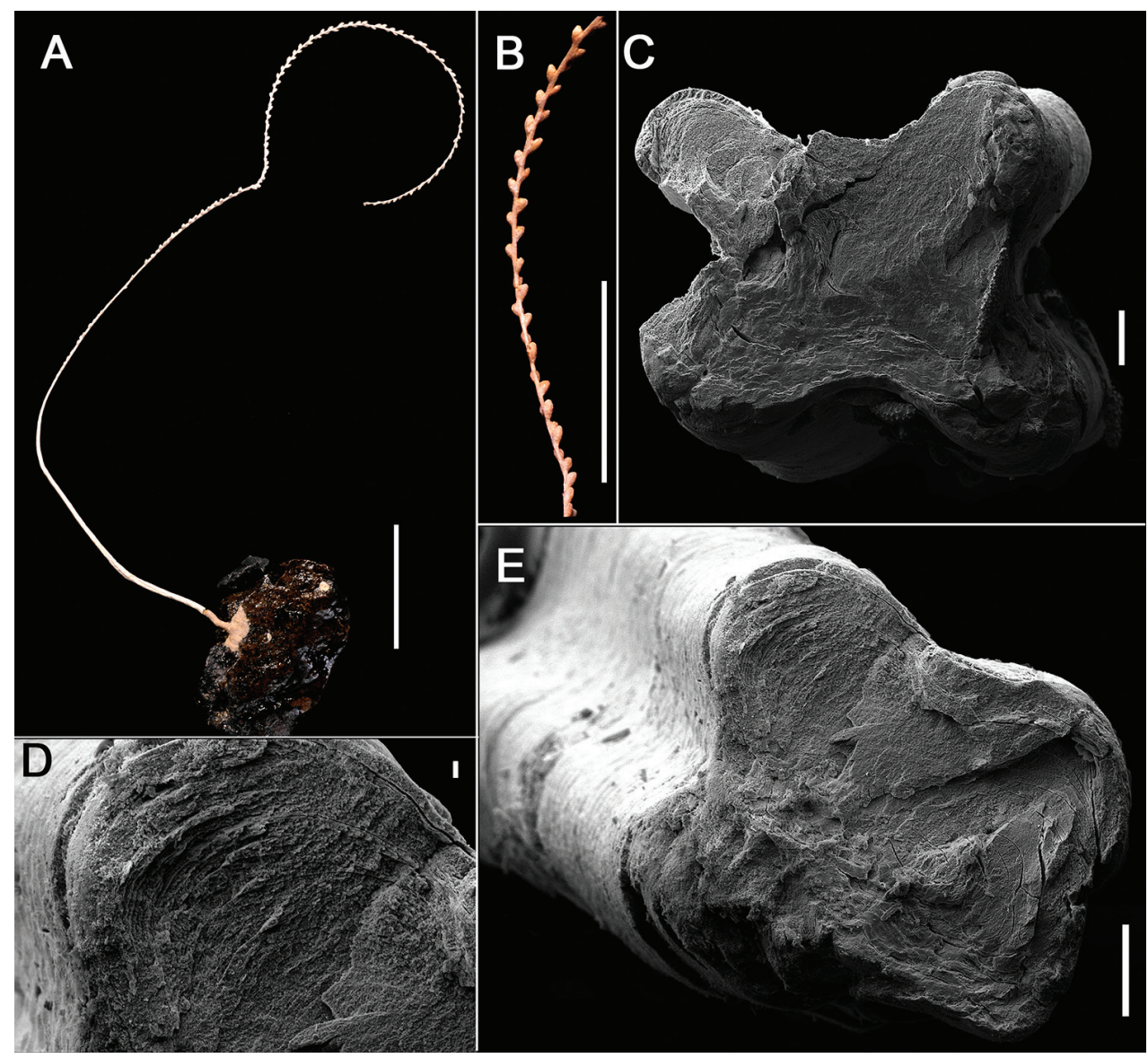

Figure I. Diagnostic characters of Flagelligorgia gracilis sp. n. A general view of the holotype (USNM 49503) attached to a rocky substrate B detail of the holotype showing the biserial arrangement of polyps $\mathbf{C , E}$ cross-section of the stem of the holotype showing its four rounded longitudinal cords $\mathbf{D}$ detail of undulating concentric layers of the stem in cross-section. Scale bars: A: $10 \mathrm{~mm}, \mathbf{B}: 5 \mathrm{~mm}, \mathbf{C}, \mathbf{E}: 0.1 \mathrm{~mm}$, D: 0.01 .

1950; Pillsbury-105, 31 ${ }^{\circ} 00^{\prime} \mathrm{N}, 79^{\circ} 42^{\prime} \mathrm{W}, 388-403 \mathrm{~m}, 2$ colonies, USNM 57316, 27 July 1964; Pillsbury-197, 2759'N, 79²0'W, 567-586 m, 2 colonies, USNM 52913, 11 August 1964.

Type locality. 3047'30"N, 7949'W (continental slope off Georgia), 494 m depth.

Description. The colony is unbranched (flagelliform) and quite delicate, with an ascending clockwise spiral growth form (Fig. 1A, 2C). One of the largest specimens (the holotype) is $19 \mathrm{~cm}$ in length and only $1.1 \mathrm{~mm}$ in basal stem diameter. Colonies are attached to hard objects such as the deep-water coral Lophelia pertusa (Linnaeus, 1758), rocks, or echinoid tests, having a thin basal encrustation (holdfast) up to 7 $\mathrm{mm}$ in diameter; there are no root-like holdfasts. The axis is longitudinally grooved (Fig. 2D), resulting in four rounded longitudinal cords (1C, E), reflecting the underly- 


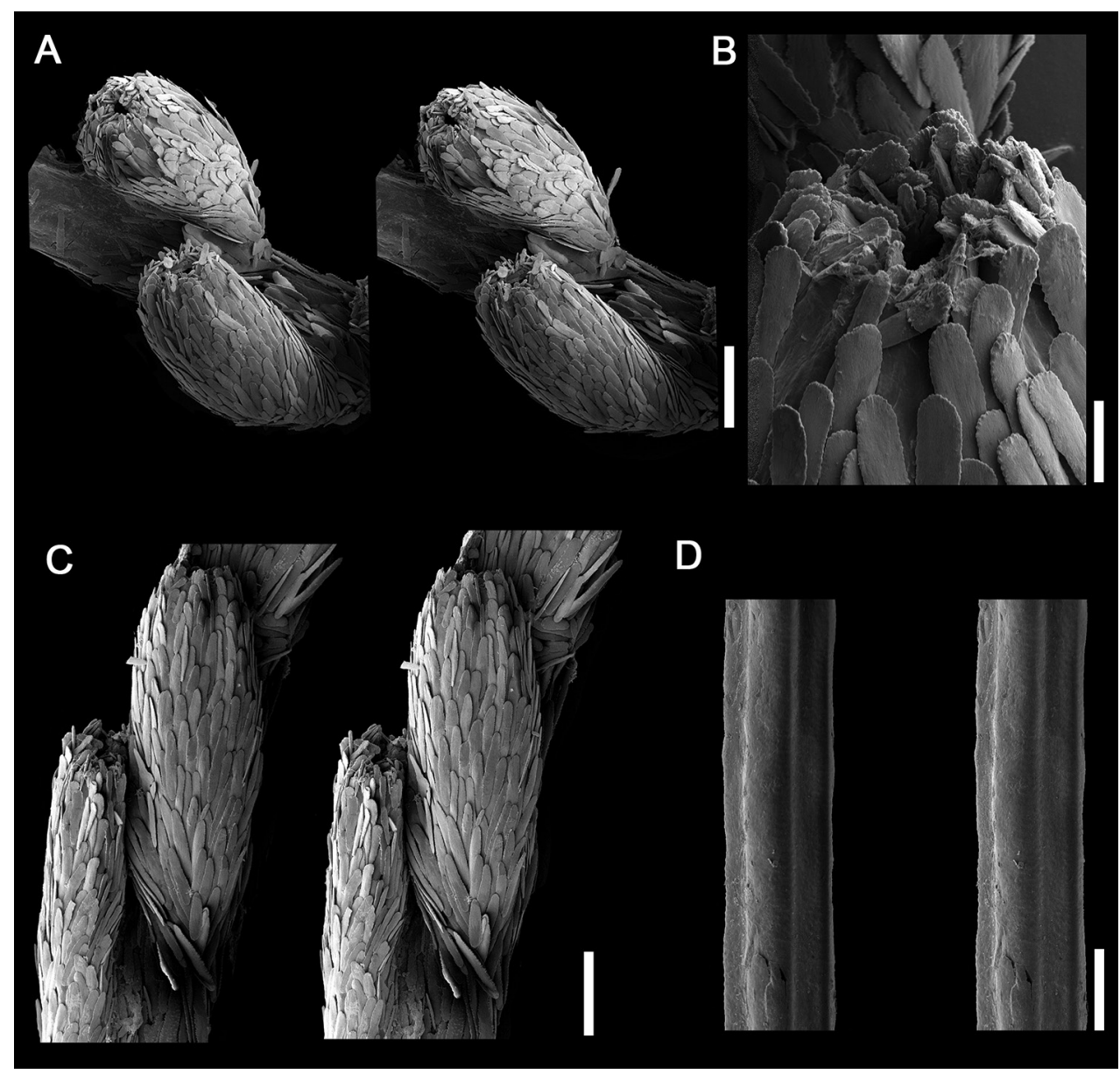

Figure 2. Detailed view of polyps and axis in Flagelligorgia gracilis sp. n. (USNM 14458) through Scanning Electron Microscopy. A stereo view of polyps B oral view of a polyp C stereo view of a polyp's abaxial side $\mathbf{D}$ stereo view of the axis. Scale bars: A, C: $0.2 \mathrm{~mm}, \mathbf{B}: 0.04 \mathrm{~mm}, \mathbf{D}: 0.01 \mathrm{~mm}$.

ing undulated layers of scleroprotein (Fig. 1D), most easily seen in stem cross section. The axis is golden, the coenenchymal tissue usually pale brown to a dull yellow, in ethanol. Polyps are lacking from the proximal $45-50 \mathrm{~mm}$ of the stem, which is approximately 1/5-1/3 of the colony length, depending on its maturity (Fig. 1A). Polyps occur biserially, on opposite sides of the stem in alternating fashion (Figs 1B, 2A, C), and are relatively closely spaced such that 1.1-1.4 polyps occur per $\mathrm{cm}$ length. The polyps are 0.9-1.2 mm in length and are somewhat cigar-shaped (Fig. 2C), being slightly tapered distally; the greatest diameter $(0.35-0.39 \mathrm{~mm})$ is usually at mid-length. The body wall is covered with longitudinally oriented, elongate ( $\mathrm{L}: \mathrm{W}=4.5-5.8)$, imbricating scales (Fig. 3B) that measure $0.17-0.24 \mathrm{~mm}$ in length. They are rounded distally, have smooth lateral edges, and are quite thin (e.g., 13-15 $\mu \mathrm{m}$ in thickness). Their outer and inner surfaces are smooth. Toward the end of the polyp are smaller scales 


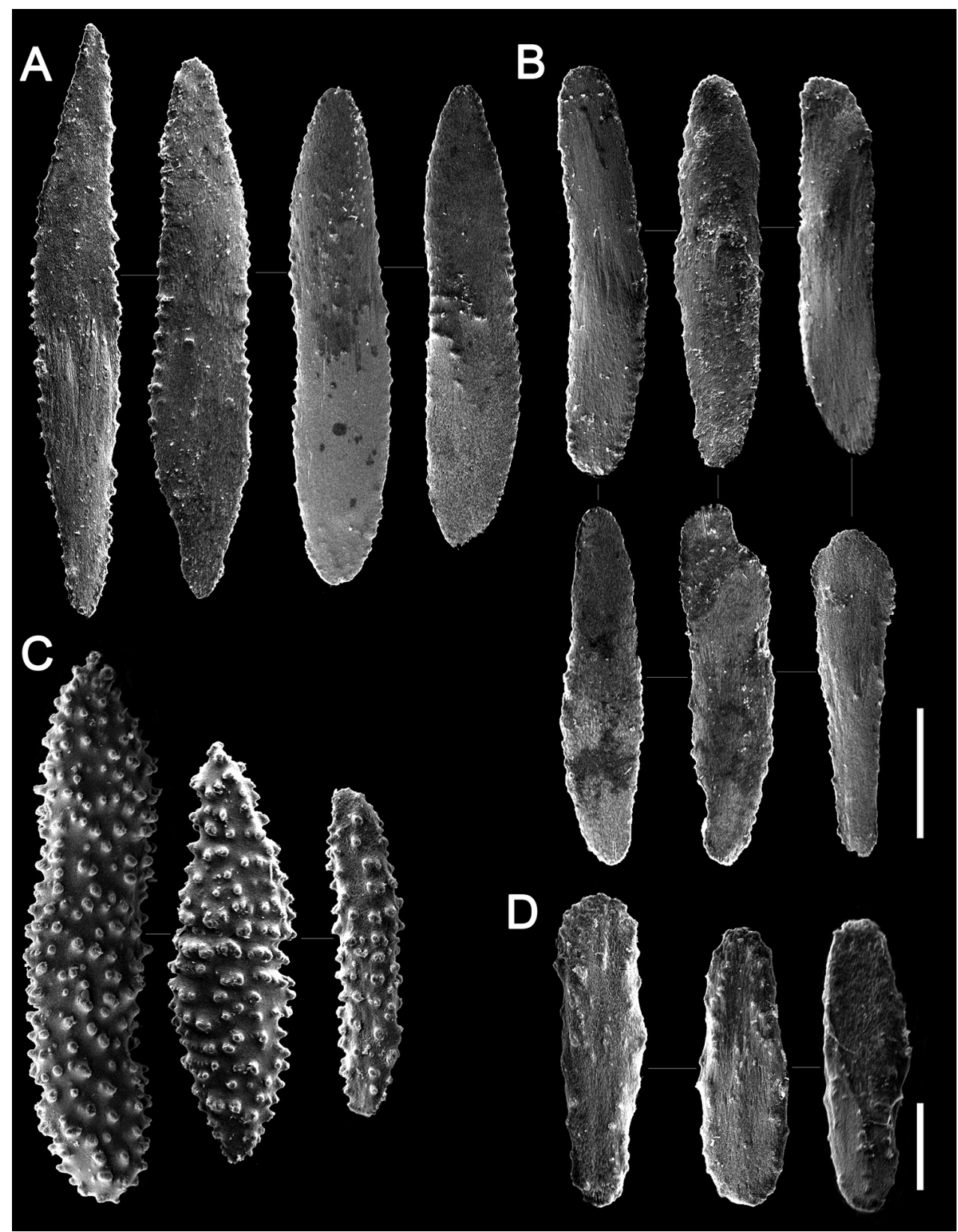

Figure 3. Sclerites of Flagelligorgia gracilis sp. n. (USNM 49503, holotype). A rods from coenenchyme B elongate rods from body wall $\mathbf{C}$ highly granular scales from first centimeters of the stem $\mathbf{D}$ tentacular scales. Scale bars: A-C: $0.05 \mathrm{~mm}$, D: $0.02 \mathrm{~mm}$.

associated with the tentacles (Figs 2B, 3D), similar in shape to the body wall scales but only $0.075-0.10 \mathrm{~mm}$ in length. Pinnular sclerites are virtually absent. Scales show concentric bands of interference colors in polarized light. There are no sclerites in the 


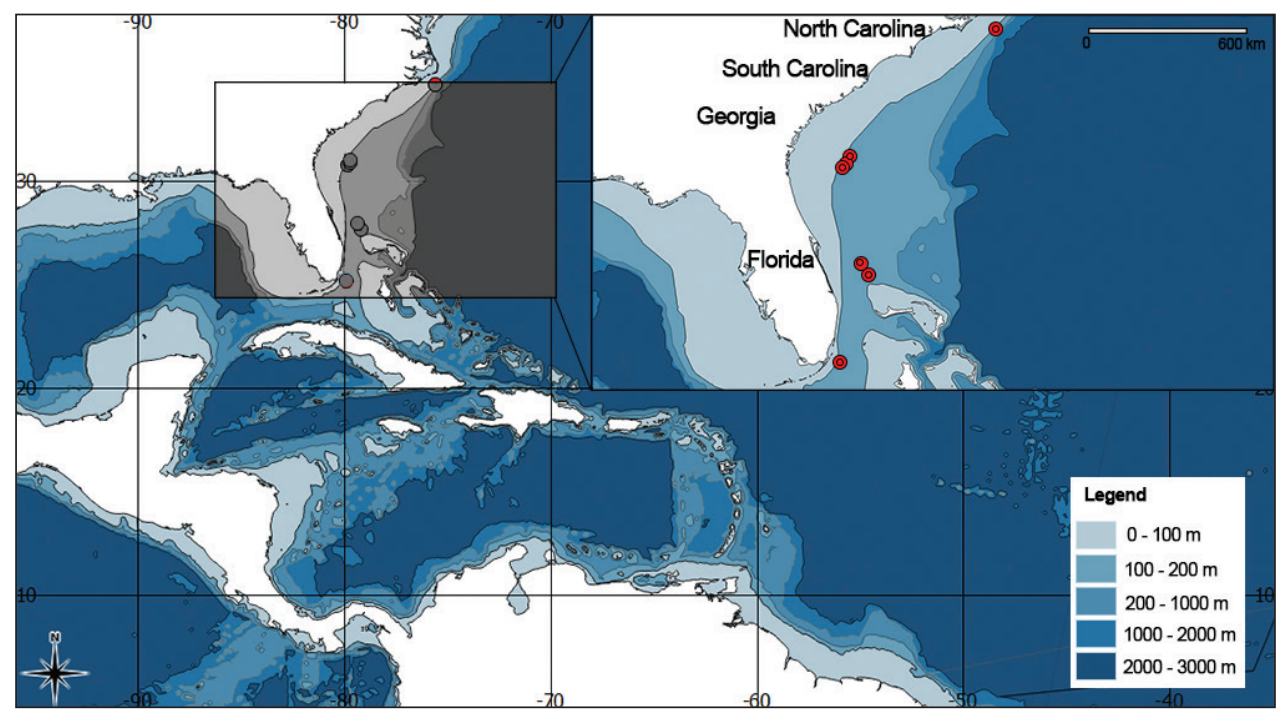

Figure 4. Distribution map of Flagelligorgia gracilis sp. n.

axial sheath of coenenchyme. The outer coenenchymal scales (Fig. 3A) are also longitudinally arranged on the stem, elongate $(\mathrm{L}: \mathrm{W}=4.8-7.9)$, and imbricate. They have pointed tips and their lateral edges are slightly serrate, each serration up to $5 \mu \mathrm{m}$ in height; they are also quite thin, and their faces are also smooth. Coenenchymal scales on the first few centimeters of the stem are highly granular (Fig. 3C).

Remarks. As in other unbranched octocorals, such as species of Radicipes, some specimens (e.g., from USNM 14458, USNM 51956 and USNM 14457) host commensal ophiuroids. Other octocoral species found at the same stations at which Flagelligorgia were collected include: Plumarella aurea (Deichmann, 1936), Plumarella pourtalesii (Verrill, 1883), Plumarella dichotoma Cairns \& Bayer, 2004, Swiftia casta (Verrill, 1883) and Callogorgia americana Cairns \& Bayer, 2002.

Distribution. Southeastern coast of United States from off Outer Banks, North Carolina to off Carysfort Reef (near Key Largo, Florida) (Fig. 4), 196-567 m depths.

Etymology. Named gracilis (Latin for slender, gracile), in allusion to the very slender aspect of the colony.

\section{Acknowledgments}

We are grateful to the reviewers Dr. Eric Pante and Dr. Scott France and to Dr. Bert Hoeksema (editor), for their valuable suggestions for the improvement of this manuscript. The second author thanks the Smithsonian for a Short Term Visitor grant, which facilitated the accomplishment of this study. RTSC was also supported by FACEPE (IBPG-0558-2.04/13), Brazil. 


\section{References}

Bayer FM (1949) Chalcogorgiinae, a new subfamily of Chrysogorgiidae (Coelenterata: Alcyonaria), and a description of Chalcogorgia pellucida, new genus and new species, from the Straits of Florida. Journal of the Washington Academy of Sciences 39(7): 237-240. http:// biodiversitylibrary.org/page/39703539

Bayer FM (1956) Octocorallia. In: Moore RC (Ed.) Treatise on Invertebrate Paleontology, Part F. Coelenterata. Geological Society of America and University of Kansas Press, Lawrence, Kansas, 163-231.

Bayer FM (1979) Distichogorgia sconsa, a new genus and new species of chrysogorgiid octocoral (Coelenterata: Anthozoa) from the Blake Plateau off northern Florida. Proceedings of the Biological Society of Washington 92(4): 876-882. http://biodiversitylibrary.org/ page/35514597

Bayer FM (1981) Key to genera of Octocorallia exclusive of Pennatulacea (Coelenterata, Anthozoa), with diagnosis of new taxa. Proceedings of the Biological Society of Washington 94(3): 902-947. http://biodiversitylibrary.org/page/34607413

Bayer FM, Muzik KM (1976) New genera and species of the holaxonian family Chrysogorgiidae (Octocorallia: Gorgonacea). Zoologische Mededelingen 50(5): 65-90. https://repository.si.edu/handle/10088/973

Bayer FM, Grasshoff M, Verseveldt J (1983) Illustrated Trilingual Glossary of Morphological and Anatomical Terms Applied to Octocorallia. E. J. Brill/Dr. W. Backhuys, Leiden, 75 pp. https://repository.si.edu/handle/10088/6237

Cairns SD (2001) Studies on western Atlantic Octocorallia (Coelenterata: Anthozoa). Part 1: The genus Chrysogorgia Duchassaing \& Michelloti, 1864. Proceedings of the Biological Society of Washington 114(3): 746-787. https://repository.si.edu/handle/10088/2462

Cairns SD, Bayer FM (2002) Studies on western Atlantic Octocorallia (Coelenterata: Anthozoa). Part 2: the genus Callogorgia Gray, 1858. Proceedings of the Biological Society of Washington 115: 840-867. https://repository.si.edu/handle/10088/7542

Cairns SD, Bayer FM (2004) Studies on western Atlantic Octocorallia (Coelenterata: Anthozoa). Part 2: the genus Plumarella Gray, 1870. Proceedings of the Biological Society of Washington 117(4): 447-487. https://repository.si.edu/handle/10088/7495

Cairns SD, Bayer FM (2009) Octocorallia (Cnidaria) of the Gulf of Mexico. In: Felder DL, Camp DK (Eds) Gulf of Mexico-origins, waters, and biota, vol 1, Biodiversity. Texas A\&M Press, Texas, 321-331. https://repository.si.edu/handle/10088/19156

Cordeiro RTS, Cairns SD, Perez CD (in press) A revision of the genus Radicipes Stearns, 1883 (Anthozoa: Octocorallia: Chrysogorgiidae). Zootaxa.

Deichmann E (1936) The Alcyonaria of the Western part of the Atlantic Ocean. Memoirs of the Museum of Comparative Zoology 53: 253-308. http://ia801409.us.archive.org/22/ items/memoirsofmuseumo53harv/memoirsofmuseumo53harv.pdf

Duchassaing P, Michelotti J (1864) Supplément au mémoire sur les corallaires des Antilles. Memorie della Reale Accademia delle Scienze di Torino 2(23): 97-206. http://biodiversitylibrary.org/page/36388394 
Grasshoff M (1999) The shallow-water gorgonians of New Caledonia and adjacent islands (Coelenterata: Octocorallia). Senckenbergiana Biologica 78: 1-245.

Haeckel E (1866) Generelle morphologie der Organismen, vol. 2. Verlag von Georg Reimer, Berlin. https://doi.org/10.1515/9783110848281

Lamouroux JVF (1812) Extrait d'un mémoire sur la classification des polypiers coralligènes non entièrement piérreux. Nouveau Bulletin des Sciences, Société Philomathique de Paris, 3(63): 181-188.

Linnaeus C (1758) Systema naturae per regna tria naturae, secundum classes, ordines, genera, species, cum characteribus, differentiis, synonymis, locis. Tomus I. Editio decima, reformata. Holmiae, Laurentii Salvii, 824 pp. http://biodiversitylibrary.org/page/726886

Pante E, France SC (2010) Pseudochrysogorgia bellona n. gen., n. sp.: a new genus and species of chrysogorgiid octocoral (Coelenterata, Anthozoa) from the Coral Sea. Zoosystema 32(4): 595-612. http://dx.doi.org/10.5252/z2010n4a4

Pante E, Watling L (2011) Chrysogorgia from the New England and Corner Seamounts: Atlantic-Pacific connections. Journal of the Marine Biological Association of the United Kingdom 92(5): 911-927. https://doi.org/10.1017/S0025315411001354

Pante E, France S, Couloux A, Cruaud C, McFadden CS, Samadi S, Watling L (2012) Deepsea origin and in-situ diversification of chrysogorgiid octocorals. PLoS One 7(6): e38357. http://dx.doi.org/10.1371/journal.pone.0038357

Perez CD, Neves BM, Cordeiro RTS, Williams GC, Cairns SD (2016) Diversity and Distribution of Octocorallia. In: Goffredo S, Dubinsky Z (Eds) The Cnidaria, Past, Present and Future. The world of Medusa and her sisters. Springer, 109-123. http://dx.doi. org/10.1007/978-3-319-31305-4

Stearns REC (1883) Descriptions of a new genus and species of alcyonoid polyp, from Japanese waters, with remarks on the structure and habits of related forms, etc. Proceedings of the United States National Museum 6: 96-101. https://repository.si.edu/handle/10088/12541

Verrill AE (1883) Report on the Anthozoa, and on some additional species dredged by the "Blake" in 1877-1879, and by the U.S. Fish Commission steamer "Fish Hawk" in 1880-82. Bulletin of the Museum of Comparative Zoology 11: 1-72. http://biodiversitylibrary.org/ page/4621758

Versluys J (1902) Die Gorgoniden der Siboga-Expedition. I. Die Chrysogorgiiden. Siboga Expeditie 13: 1-120.

Watling L, France S, Pante E, Simpson A (2011) Biology of deep-water octocorals. In: Lesser M (Ed.) Advances in Marine Biology. Elsevier Academic press, London, 41-122. http:// dx.doi.org/10.1016/B978-0-12-385529-9.00002-0

Williams GC (1992) The Alcyonacea of southern Africa. Gorgonian octocorals (Coelenterata, Anthozoa). Annals of the South African Museum 101(8): 181-296. http://biodiversitylibrary.org/page/40683324 